\title{
A Brief Analysis of the Essence of Education and Human Ethics-Hegel's View
}

\author{
A. L. M. Riyal ${ }^{1}$ \\ ${ }^{1}$ Department of Social Sciences, South Eastern University of Sri Lanka, Oluvil, Sri Lanka \\ Correspondence: A. L. M. Riyal, Department of Social Sciences, South Eastern University of Sri Lanka, \\ University Park, Oluvil \# 32360 Sri Lanka. E-mail: almriyal@seu.ac.lk
}

Received: March 17, 2019

doi:10.5539/jpl.v12n2p79
Accepted: May 12, $2019 \quad$ Online Published: May 30, 2019

URL: https://doi.org/10.5539/jpl.v12n2p79

\begin{abstract}
Education and ethics were like two sides of a coin. This was stated by Hegel in the early modern period. However, these two concepts are viewed separately in the contemporary era. Therefore, the objective of this paper is to analyze both education and ethics enabling the well-ordered society to understand the relationship between education and ethics. The methodology adopted for this study was descriptive based on the previous literature. Hegel pointed out that ethics is the essential requirement of human beings and the reasonable way of individual existence. Only when individuals become members of the state can they truly achieve freedom and liberation. Education should be ethical education, that is, education is the intermediary of the individual's free will to realize the ethical essence. Education should remove the individual's subjective capriciousness and individualism, make them integrate into the ethical entity constituted by the social system and historical tradition, and realize the individual's self-improvement in the ethical entity. Hegel's principle of the philosophy of law is a work of political philosophy, which contains abundant educational thoughts. By discussing the self-movement process of objective spirit, Hegel explains how to realize the reasonable existence of man, that is, the existence as ethics. Ethics is the essence of human determinacy, which refers to the unity of individual will and universal will. It is only as a member of the ethical entity that an individual can truly gain freedom and liberation. Hegel pointed out that the highest ethical entity is the state. The ethical nature of an individual is reflected in becoming a citizen of the state.
\end{abstract}

Keywords: Hegel, ethics, freedom, education, family

\section{Law and Ethics}

Hegel said that "law" is "the determination of free will" and "law is freedom as an idea" (Roscoe Pound, 1923: p.46). The rational way of individual existence is the unity of subjective will and objective norm, and its highest stage is ethics. Hegel's "ethics" is different from the facts and norms of interpersonal relations in moral philosophy, but it refers to the social relations system and its objective order that constitute the basis of value rationality (Timothy C Luther, 2009:pp.117-119). That is, the collective will and national customs and customs, "ethics" is the "abstract law" and "moral" links of dialectical unity. The abstract law is the objective element, that is, the abstract free will initially maintain itself in possession and exchange of the external, being right and proper, but it is the self without subject consciousness, because the external is accidental, uncertain, and in the face of competition and consumption, the self cannot establish a complete self in the external (Pelczynski, 1984:pp.201-203).

"Ethics" is the law of the subjective mind, it is the self-reflection of the individual heart, and it overcomes the dependence of external things. However, it is not realistic to start from the subjective universality and lack the objective standard and system as the measure and judgment."Ethics" is a reasonable way of individual existence. It is the integration of individual subjective will and group norms and systems. Individual freedom can only be truly realized in an ethical way.

\section{Family, Civil Society and the State}

In the Philosophy of Right Hegel subdivides the sphere of ethical life into a family, civil society and the state (Pelczynski, 1984:p.8). The family is the direct substantive reality of spirit, the unity of the family is one of feeling, the feeling of love (Georg H. W. Hegel, 2008:p.82). It is valued as the place where one first learns about 
one's roles and duties as a human being and also where one learns to practices fulfilling those roles and duties (Gerhold K. Becker - 1996:p.17). So, the family is the starting point of the essence of individual ethics. The family has "simple" unity. Hence in a family, one's frame of mind is to have self-consciousness of one's Individuality within this unity as the absolute essence of oneself, with the result that one is in it not as an independent person but as a member(Georg H. W. Hegel, 2008:P.82).

The prescriptive nature of the family is love, a feeling that one is unified with others (Ruiping Fan, 2015:p.191). "Love is, in general, the consciousness of the unity of my- self with another. I am not separate and isolated but win myself- consciousness only by renouncing my independent existence, and by knowing myself as the unity of myself with another and of another with me" (Georg H. W. Hegel, 2008:P.82)

The family is an entity formed by the parents by giving up their independence, and the children are born in such an ethical form of identity. However, because "love" is a subjective and accidental feeling and lacks the support of rationality, the family is just a "simple" (unstable) ethical entity, and children cannot obtain complete and mature freedom in the family. When children grow up and live independently from the family they enter the second link, "civil society" (Pauli Siljander; Kimmo Kontio; Eetu Pikkarainen, 2017:p.98).

The significance of civil society for individuals lies in the independent reality of individuals, which is marked by individual rights. Civil society is "the system of needs" (John R. Ehrenberg, John E. Ehrenberg, 1999:P.126) and a field in which individuals fight for their own interests. In civil society, 'The concrete person, who is himself the object of his particular aims, is, as a totality and a mixture of caprice and physical necessity, one principle of civil society.' However, the particular person is essentially so related to other particular persons that each establishes himself and finds satisfaction by means of the others and at the same time purely and simply by means of the form of universality, the second principle here(Ibid. 125).

In the process of labor for personal desire, the individual still has the potential universality, that is, the collaboration and association in labor. People must face the common labor resources and the need for product exchange, which makes "universality is that people affirm themselves in the relationship of satisfying the needs of others and being free and capricious".

"The state" is the third link of ethics - " The essence of the modern state is that the universal be bound up with the complete freedom of its particular members and with private well- being, that thus the interests of family and civil society must concentrate themselves on the State, although the universal end cannot be advanced without the personal knowledge and will of its particular members, whose own rights must be maintained" (John McGowan, 1991:p.59).

It is only in the state that, individuals can obtain real freedom. For the individual, whether as a family of simple identity or as a citizen fighting for his own desire, is not sufficiently free in universality. Only the dialectical unity of the two can be reasonable, that is, the right to freedom is truly realized.

So the reasonable way for an individual to exist is to become a citizen of the state. However, the specific freedom lies in the fact that the singleness of individuals and their special interests are not only fully developed, but also their rights are explicitly recognized. Being a member of the state is the highest duty of the individual because the reasonable existence of the person can only be realized in the ethical entity of the state (Hans Kelsen, 2007:pp.9-10).

\section{The Individual's Ethics}

How to understand that "ethics" is a reasonable way of individual existence? From the perspective of the formation of ethics, as a group fashion and institutional customs, ethics is the common creation of mankind. Hegel distinguishes between 'law 'and 'true law', this distinction is made from a standpoint of justice that holds universally for all states (Thom Brooks, 2013:P.95), which are "outside of us, to which our knowledge neither augments nor assists, to which our knowledge enlarges the field of our knowledge, and nothing more. Also, "the law is made for man and not man for the law" (Robert R Williams, 1997: p.192).

Furthermore, to obey the laws of nature which are different, everyone has a method, measured by it and not admitted it, because the facts of law require method conform to our common standard. This suggests that the individual's free will, in essence, belongs to the category of practice, as a system. Thus, specification of the contents of ethics is essentially human legislation itself, its rationality is also gradually formed in the people's understanding and practice, rather than like a law of nature is outside the people's will.

Therefore, ethics is essentially the common will formed by history, which is the embodiment of human's free will ( Habib, Rafey Habib,2018:pp.56-57). The difference between individuals constitutes the specific content of the ethical state, and ethics is the reasonable social interaction between people's material and spiritual life. Due to 
this, ethics does not depend on an individual's subjective opinions. Once the social relationship structure is formed, it is not controlled and decided by the individual. Its development is shown to a certain degree of objective autonomy.

From the content of ethics, firstly, ethics is the constitutive condition of the individual free will (Robert R. Williams, 1998:P. 88). So we can have free will only if we accept the boundaries and the framework within which we are, without which we cannot have a full sense of the self because we do not know "who am I?" According to Charles Taylor, a contemporary Hegelian philosopher: "To know who I am is a species of knowing where I stand. My identity is defined by the commitments and identifications which provide the frame or horizon within which I can try to determine from case to case what is good, or valuable, or what ought to be done, or what I endorse or oppose. In other words, it is the horizon within which I am capable of taking a stand" (Charles Taylor, 1992: p.27). Ethics as a constructive framework of free will refers to the history, the first is the common value of the individual, group background and the way of life. Thus, we know them and on the basis of the value choice, that is to say, we are the first by accepting the influence of education or other ways to form his own personality and value position, to talk about the independent activity. This effect must be from our own groups such as family and community. Individuals have no choice but to find their own social space, so the group is the starting point and premise of independent choice.

In Hegel's view, the state and society logically precede the individual. Although the individual was born before the state in real history, being a member of the state and the group is the basis of individual sociality and the constitutive condition of individual freedom. Hegel actually emphasizes the "group nature" of individuals through "ethics" (Oona Ceder, 2000:p.446).

Secondly, ethics is the transcendence of individual nature. In Hegel's view, the "rational purpose is to remove the natural plain, without my part is negative, the other part is the simple nature of the knowledge and the will, the spirit of the potential of directness and simplicity, and renders the spirit of the exteriority is suitable for the rationality of it, namely, the form of universality or rational. Only in this way it can be the spirit feeling at home in the pure externality itself. So according to Hegel people's free will has two meanings, namely natural freedom and ethics life, ethics is a kind of freedom outside individual particularity, human universal and developed through mutual life ought to be the human nature (Allen W. Wood, Wood Allen W, 1990:pp.36-38). It is the "nature" -- that is, quite naturally overcome, also is the people from the negative state without me, the dependence on family, at the same time make the individuals be included within the common community. This is through the national system of coordination and distribution of division of labor which overcomes selfishness, and a life-and-death battle for civil society, make the individual become a member of the unified social organism, the national citizens (Adriaan T Paperback, 1987:pp.75-80).

The reason for this is that the particularity of purely natural human nature will lead to self-expansion, exclusion, conflict, and disintegration. There is a lack of sense of identity among individuals. Social morality presents relative values. However, the simple universality will bring the autocracy, the dogma and the rigid, its price cuts the foot to fit the shoes and sacrifices the development of many possibilities. Therefore, the rationality of ethics lies in the fact that universality gains its own vitality and authority and individual freedom can be specifically realized by suiting and discarding particularity (preservation and transcendence). This process is the unity of purposiveness and regularity through the understanding and grasping of the internal law and power of social development in the historical tradition of common life and in specific human activities.

As Christian said; "the true universality is not separated from the special things in history. Thus, we see universality in this way: mankind is aware of it only in its concrete form. Through the integration of universal will, including institutions and national customs, individuals transcend the one-sided nature and obtain the higher value of human beings. It contains Hegel's reflection on the capitalist mode of production at that time. The class antagonism and capital competition in civil society make people increasingly one-sided and indifferent. Everyone pursues the satisfaction of desire. Hegel emphasizes the difference between the state and civil society, which requires the state, as an ethical entity, to restrain the nature of labor's desire through institutional force, so that the citizen will not be alienated by labor and become the real master of labor. Moreover, through the provision of specific and universal individual rights and obligations, the individual can improve himself into a universal existence and obtain the natural nature of human beings (Georg H. W. Hegel, 2008: pp.85-89).

\section{Education and Human Ethics}

As the transcendence and improvement of man's natural essence, education is an important medium for the realization of ethics. Hegel pointed out that, the aim of education is, first of all, to instill ethical sense into immediate feeling and sensibility (Fred Reinhard Dallmayr, 2002:p.122).”Education [Pädagogik] is the art of 
making human beings ethical: it considers them as natural beings and shows them how they can be reborn, and how their original nature can be transformed into a second, spiritual nature so that this spirituality becomes habitual to them" (Georg Wilhelm Fredrich Hegel:, Allen W Wood; Hugh Barr Nisbet, 1991:p.195) Hegel's ethical education emphasizes three aspects. First, education must cultivate rational self-control of subjective desire. The second is to cultivate children's awareness of conforming to objective norms and being members of a group and eliminate children's pure individuality. Third, the education development cannot leave the real life and the traditional experience opposes the idealized education design which is divorced from the reality and the historical foundation (Alison Stone, 2005: pp. 115-116).

Ethical education must first cultivate rational self-control, namely the self-control of instinct and desire. Hegel pointed out that (education) this kind of work opposes the purely subjective capriciousness of action, the directness of desire, as well as the subjective asexual of feeling and the capriciousness of preference. "The meaning of caprice is that the content is not determined as mine by the nature of my will, but by contingency; thus, I am just as much dependent on this content. (Mark William Roche1998, : P.188) What Hegel means by capricious is that he regards the satisfaction of natural desire as freedom and education as the tool to realize material desire. It extracts people's biological instinct and preference as the purpose of life and forms the natural and free view of enjoyment. Individuals are actually enslaved by external objects and their own desires and preferences. This is a misunderstanding of freedom, and this kind of education cultivates what Nietzsche calls "the last man" " Once you were apes, and even now man is more of an ape than any ape "(Christa Davis Acampora, Ralph R. Acampora, 2004:p.319). Hegel said: "how should be a person, not by instinct, but must work hard." Man is human not only because he has the nature of nature, but also because he has the "second nature", that is, the ethical essence of man. It is realized through rational self-control of desire, and education should liberate people from their own nature and dependence on external things (Andreja Novakovic, 2017:pp.44-47).

Hegel believes that overcoming willfulness mainly lies in the stage of family education. Family education must prepare children to enter social life in the future so that children can overcome the directness of nature, achieve independence and free personality, and thus achieve the ability to break away from the family's natural unity. The purpose of family education is "to inculcate ethical principles", "to warn against freedom which is still confused by nature, and to mold the universal into their consciousness and will". That is, to let children learn the principles of living together and learn to use universal reason to control their own instincts and desires (Guy Standing, 2009: pp.255-257).

The formation of ethical concepts lies in discipline and habits. "The main link of education is discipline, which means to break the children's self-will and remove the pure sensibility and nature". Therefore, the requirement of education on discipline is to eliminate children's own private preferences and cultivate rationality. At the same time, Hegel emphasized the significance of habit formation in education. "Education is the art of making men ethical: it starts from man's naturalness and points the way to a rebirth whereby his first instinctive nature is transformed into second, intelligent nature, rendering the letter habitual. At that point, the conflict between natural and the subjective will disappears, the struggle of the subject (with itself) subsides, and habit becomes part of ethics(Fred Reinhard Dallmayr, 2002:p.177). Through discipline and habit cultivation, ethical education points out the path of "regeneration" to children, that is, the path of forming ethical humanity. Education makes people become masters of their own inner natural desire. Therefore, Hegel pointed out that education is a kind of "hard work". Education should not only be about joy and pleasure, but also about hard work. Hegel criticized the "childish" "game theory" education, saying that it would make children stay immature and generate conceit that belies adults.

Secondly, ethical education should cultivate children's collective concepts and make them become members of the social organism. This needs to overcome the pure individuality of children's self-centeredness. Hegel said, a cultivated man is 'first and foremost' (David V Ciavatta, 2009: p.19) a man who can do what others do without expressing his specificity, and an uncultivated man is about to express that specificity."This is because people are social animals; only learn to live together, in social groups to obtain freedom which is more valuable freedom. This freedom is not the impersonal universality that negates particularity, but the unity of the two. "The particularity gives the universality its substantial content and its infinite self-definition so that in its own ethics it becomes an infinite independent and free subjectivity." Therefore, ethical education opposes the educational purpose of individualism. Individualism sets individual will against the collective concept, questions the legitimacy of valuable guidance, equates authority with control, and regards guidance as an infringement on individual freedom and rights. "The dark side of individualism is self-centeredness, which makes our lives mediocre and narrow, and makes our lives less meaningful and less caring for others and society. 
Hegel pointed out education is to consider the particularity of the family; its behavior is in line with the nature of things. Through education, children learn to cooperate with others, accept the opinions of others, and learn to recognize and respect common beliefs and values. It is a new particularity; a free and reasonable particularity that makes the individual subjective special will become the universal existence of social spirit.

Hegel believes that labor education is an important way to cultivate the concept of collective. In the process of labor, the individual meets the needs of his life and produces the needs of labor. At the same time, through collective labor and division of labor, we establish social relations with others. Since "I acquire my means of satisfaction from others and must accordingly accept their opinions. But at the same time, I am compelled to produce means whereby others can be satisfied" (Robert R Williams, 1997: p.192). Thus they cooperate with each other and are connected to each other, and thus all individual things become social. Labor that makes people meet the individual needs and meet the requirements of other people and society, and by increasing the commonwealth and curb the labor Semi motivation, form the idea of sharing work achievement, overcoming their own desires limitless and working for the individual to realize personal interests and the interests of others. Furthermore, if the national interest is inseparable, the individual is not only in labor for self-gratification. Moreover, in the process of labor, individuals participate in creating their own social tradition and custom civilization, and the relationship between individual subjectivity and the ethical entity is reflected in the process of labor.

At the same time, Hegel emphasized that education should be based on real human nature and real life, and seek inevitability in the common historical experience. He has criticized an abstract individualism education, the education in fiction "natural state" of human nature as a blueprint, believe that can be separated from the social environment and traditional ideas in order to develop education - this is the education, Rousseau's romanticism "educators want to a man from daily life, and education in the country he (e.g., Rousseau's love Milton). However, the experiment has failed, because making people attempt to rule the world with hydrophobic partition is impossible. Although the education of youth must be carried out in remote surroundings, it must not be supposed that the fragrance of the spiritual world does not blow over this tranquil place, nor that the spiritual power of the world is too weak to occupy these remote areas. Romanticism educational view sets society against individuals, regards education in social life as "external things and corrupting things", breaks away from the reality of human nature, severs the root of individual social tradition, and reconstructs the educational concept from the fictional perfection of human nature, and hopes to transform the society with it. As Rousseau said in his theory of social contract: "capable, so to speak, of changing human nature, of transforming each individual, who is by himself a complete and solitary whole, into part of a greater whole from which he . . receives his ... The legislator must transform civil society from a mere aggregate of isolated, externally related individuals into a community (Robert R. Williams, 2000:p.278). In short, the man must be stripped of his inherent power in order to give him power beyond himself that he cannot use without the help of others. The more these natural forces are eliminated, the more they are gained, the more they endure, the more the system is consolidated and perfected.

Therefore, he replaced the actual condition of human nature with the hypothesis of the goodness of nature and extended the whole society (" general will ") by a single individual. When Rousseau's abstract freedom became law, it became destruction to human nature. So romantic education want to replace all the diversity, the abstract individual for each student in moral ideal and for example, hope education become a redesigned chemical change of human nature, but it is only in the education depression in children, the hypocrisy and the division of the moral consciousness, will eventually make the children. This is only because of the uncertain pursues the personal tangible utilitarian.

Romanticism education denies the fact that the individual and society are mutually constituted and also cut off the common historical tradition of society. Hegel's emphasis on ethical education aims at overcoming romanticism's negation of history with a historical and common ethical concept. As he said of the state system: "every nation has a state system fit for itself and belonging to it. ...... A constitution is not just something manufactured; it is the work of centuries, it is the Idea, the consciousness of rationality so far as that consciousness is developed in a particular nation" (Gary B. Herbert, 2003: p.214). It is precise because universality presents its own vitality in the special things of history that, ethical education advocates the determination of educational purposes.

Moreover, the methods on the basis of the objects are in ethical order within the framework of common historical concepts, pay attention to the inheritance of reasonable concepts in traditions, and maintain the historical continuity of groups. It regards tradition as an important spiritual resource endowed with sociality by individuals. Only by criticizing and reflecting on the basis of tradition can be individuals which maintain their 
identification with the society and avoid falling into the atomization of individualism and society. At the same time, it also believes that the realization of individual potential is a never-ending process, and the universality of ethics is also a process of constant renewal. Therefore, ethical education is carried out in daily life to cultivate the inheritance of traditional concepts, aiming to realize the orderly development of individuals and society.

Despite the fact that education and ethics need to be spoken as the phenomenology of spirit, Allen W. Wood (1998) explains Hegel's phenomenology of spirit as the research object. Hegel's views on children's education are of the great reference value. The main ideas on children's education in the phenomenology of spirit, Hegel divides education into two categories. The first category is Bildung, a long-term, internal process of discovering and solving conflicts and contradictions. The second category, Upbringing, it is to point to parents, teachers on children's education. Hegel first believed that the second type of education, that is, the education of children provided parents and teachers, mainly aims at overcoming the human nature of "desire must be satisfied immediately" and enriching children's spiritual world through knowledge and thought.

So far, Hegel's views on education can be summarized as follows:

First, wants to pass external force; cultivates the habit that builds children delay to enjoy. In Hegel's words, it is "the freedom from the impulsive desire in the material life, the acquisition of the ideal thought and the principle of universality". This habit or "principle of universality" is irrational.

Second, education is also for children and adults to acquire the ability to think abstractly and constantly renew their understanding of things. In Hegel's words, it is "a process of self-improvement, self-transformation, and self-evolution on the rational level by using abstract thinking and logical thinking, so as to be able to speculate on the known and unknown things". The process is rational.

\section{Conclusion}

The educational thought in Hegel's philosophy of law embodies the essence of his philosophy, which covers the internal unity of individual and group development. As Dewey pointed out in democracy and education, (Hegel's concept of education) is to consciously combine the complete realization of personality with the complete and regular obedience to the existing system that he emphasized the ethical mission of education. As the essence of human strain, ethics focus on human happiness and perfection which are unified. In fact, the purpose of ethical education is to realize the essence of human ethics, make individuals the existence of ethics, and realize the freedom and liberation of human beings. Therefore, ethical education is an intermediary of human self-improvement and an inevitable link to social development.

\section{References}

Acampora, C. D., \& Acampora, R. R. (2004). A Nietzschean Bestiary: Becoming Animal Beyond Docile and Brutal. Lanham, Md.; Oxford: Rowman \& Littlefield.

Becker, G. K. (1996). Ethics in Business and Society: Chinese and Western Perspectives. New York: Berlin Springer. https://doi.org/10.1007/978-3-642-61442-2

Ceder, O. (2000). The family, the state, and citizenship in Aristotle's, G.W.F. Hegel's, and J.S. Mill's political thought. Stanford University. Dept. of Political Science (Ph.D. Diss) pp. 446.

Ciavatta, D. V. (2009). Spirit, the family, and the unconscious in Hegel's philosophy. Albany: State University of New York Press.

Dallmayr, F. R. (2002). G.W.F. Hegel: Modernity and Politics. Lanham, Md.: Rowman \& Littlefield.

Ehrenberg, J. R., \& Ehrenberg, J. E. (1999). Civil Society: The Critical History of an Idea. New York: NYU Press.

Fan, R. P. (2015). Family-Oriented Informed Consent: East Asian and American Perspectives. Cham: Springer. https://doi.org/10.1007/978-3-319-12120-8

Habib, Rafey Habib, M. A. R. (2018). Hegel and the Foundations of Literary Theory. Cambridge: Cambridge University Press. https://doi.org/10.1017/9781108602952

Hegel, G. H. W. (2008). Philosophy of Right. New York: Cosimo, Inc.

Hegel, G. W. F., Wood, A. W., \& Nisbet, H. B. (1991). Hegel: Elements of the Philosophy of Right. Cambridge [England]; New York: Cambridge University Press. https://doi.org/10.1017/CBO9780511808012

Herbert, G. B. (2003). A Philosophical History of Rights. New Jersey: Transaction Publishers.

Kelsen, H. (2007). The Political Theory of Bolshevism: A Critical Analysis. Berkeley: University of California 
Press.

Luther, T. C. (2009). Hegel's critique of modernity reconciling individual freedom and the community. Lanham, MD Lexington Books.

McGowan, J. (1991). Postmodernism and Its Critics. Ithaca: Cornell University Press.

Novakovic, A. (2017). Hegel on Second Nature in Ethical Life. Cambridge: Cambridge University Press. https://doi.org/10.1017/9781316809723

Pelczynski, Z. A. (1984). The State and Civil Society: Studies in Hegel's Political Philosophy. Cambridge: Cambridge University Press CUP Archive.

Peperzak, A. T. (1987). Philosophy and Politics: A Commentary on the Preface to Hegel's Philosophy of Right. Dordrecht: Springer Science \& Business Media. https://doi.org/10.1007/978-94-010-9624-9_4

Pound, R. (1923). Interpretations of Legal History. Cambridge: Cambridge University Press.

Roche, M. W. (1998). Tragedy and comedy: a systematic study and a critique of Hegel. Albany, NY: State Univ. of New York Press.

Siljander, P., Kontio, K., \& Pikkarainen, E. (2017). Schools in transition: linking past, present, and future in educational practice. Rotterdam, The Netherlands: Sense Publishers. https://doi.org/10.1007/978-94-6300-827-3

Standing, G. (2009). Work after globalization: building occupational citizenship. Cheltenham, U.K.; Northampton, Mass.: Edward Elgar. https://doi.org/10.4337/9781849802376

Stone, A. (2005). Petrified Intelligence: Nature in Hegel's Philosophy. Albany: State University of New York Press.

Taylor, C. (1992). Sources of the Self: The Making of the Modern Identity. Cambridge, Mass: Cambridge University Press.

Thom Brooks. (2013). Hegel's Political Philosophy. Edinburgh: Edinburgh University Press.

Williams, R. R. (1997). Hegel's ethics of recognition. Berkeley: University of California Press.

Wood, A. W. (1990). Hegel's Ethical Thought. Cambridge: Cambridge University Press. https://doi.org/10.1017/CBO9781139172257

Wood, A. W. (1998). Hegel on Education. In A. O. Rorty (Ed.), Philosophy as Education (pp. 4-10). London: Routledge.

\section{Copyrights}

Copyright for this article is retained by the author(s), with first publication rights granted to the journal.

This is an open-access article distributed under the terms and conditions of the Creative Commons Attribution license (http://creativecommons.org/licenses/by/4.0/). 